\title{
Salinity Induced Changes in hydrogen peroxide, Lipid Peroxidation, Antioxidant Enzymes Activities and Yield Attributes in Chickpea (Cicer arietinum L.) Cultivars
}

\author{
Dharamvir*, Neeraj Kumar, Ajeev Kumar, Mahesh Kumar and Parveen Kumar
}

Department of Botany and Plant Physiology, CCS Haryana Agricultural University, Hisar125 004, Haryana, India

*Corresponding author

\section{Key w ords \\ Antioxidant, Cicer arietinum, Days after sowing, Hydrogen peroxide, Lipid peroxidation \\ Article Info \\ Accepted: \\ 15 November 2018 Available Online: \\ 10 December 2018}

\section{A B S T R A C T}

Salinity in soil or water is one of the major stresses and especially in arid and semi-arid regions, can severely limit crop production. Chickpea (Cicer arietinum L.)is sensitive to salinity that affects its yield and there is need to identify the tolerant genotypes. In order to evaluate the effect of soil salinity, a pot experiment with two chickpea genotypes was carried out under screen house conditions. The required amounts of chloride and sulphate salts of $\mathrm{Na}^{+}, \mathrm{Ca}^{+2}$ and $\mathrm{Mg}^{+2}$ were added through $\mathrm{NaCl}, \mathrm{Na}_{2} \mathrm{SO}_{4}, \mathrm{CaCl}_{2}, \mathrm{MgCl}_{2}$ and $\mathrm{MgSO}_{4}$. Sodium and $\mathrm{Ca}^{+2}+\mathrm{Mg}^{+2}$ were in the ratio of $1: 1$ where $\mathrm{Ca}^{+2}$ and $\mathrm{Mg}^{+2}$ were in the ratio of $1: 3$ to develop three $\left(2.0,4.0,6.0 \mathrm{dS} \mathrm{m}^{-1}\right)$ levels of saline soil before sowing. The control plants were irrigated with distilled water. Sampling was done at 5060 days after sowing. The hydrogen peroxide of leaves and roots and lipid peroxidation (MDA) of leaves and roots increased significantly in both the genotypes under different salinity levels. The $\mathrm{H}_{2} \mathrm{O}_{2}$ content increased significantly by 0.380 to 0.625 and 0.366 to 0.579 (moles $\mathrm{g}^{-1} \mathrm{DW}$ ) $\mathrm{x} 10^{-4}$ in leaves at 50-60 DAS in the genotypes CSG-8962 and HC-3, respectively with increasing the level of salinity. In roots, at 50-60 DAS, $\mathrm{H}_{2} \mathrm{O}_{2}$ content increased significantly from 0.260 to 0.470 in the genotype CSG-8962 and 0.217 to 0.401 (moles $\mathrm{g}^{-1} \mathrm{DW} \times 1_{-4}$ ) in the HC-3, with increase in salinity levels from control to $6.0 \mathrm{dS} \mathrm{m}^{-1}$. In leaves, at 50-60 DAS, a significant accumulation of MDA content was observed in both the genotypes under salinity levels. This increase was from 13.40 to $21.43 \mathrm{n}$ moles $\mathrm{g}^{-1}$ dry weight in the genotypes CSG-8962 and 13.38 to 17.43 in HC-3 with increasing levels of salinity from control to $6.0 \mathrm{dS} \mathrm{m}^{-1}$. In roots, an increase from 10.35 to $16.59 \mathrm{n}$ moles $\mathrm{g}^{-1} \mathrm{dry}$ weight in MDA content was observed in the genotype CSG-8962, however, in HC-3, this was from 10.55 to 13.83 with increasing levels of salinity from control to $6.0 \mathrm{dS} \mathrm{m}-1$ at $50-60 \mathrm{DAS}$. The specific activities of ROS scavenging enzymes such as SOD, CAT, POX, APX, GPX, GR and GST increased in leaves of both the chickpea genotypes, upon increasing levels of salinity from control to $6.0 \mathrm{dS} \mathrm{m}^{-1}$ at 50-60 DAS. The increase was more in HC-3 as compared to CSG-8962. Despite the increase in the activity of these enzymes, AsA content decreased 42.3 and $36.1 \%$ in the leaves of CSG-8962 and HC-3, respectively. Higher activities of antioxidant enzymes, lower accumulation $\mathrm{H}_{2} \mathrm{O}_{2}$, MDA and AsA content in HC-3 than in CSG-8962 indicated that these enzymes play a key role in removal of ROS better in HC-3 than CSG-8962, thus minimizing the cellular damage caused by ROS under salinity levels. The yield parameters like number of branches plant ${ }^{-1}$, number of pods plant $^{-1}$, number of seeds plant ${ }^{-1}, 100$ seed weight and seed yield plant ${ }^{-1}$ decreased more in CSG-8962 than HC-3 with increasing salinity levels from control to $6.0 \mathrm{dS} \mathrm{m}^{-1}$. The reduction is more in CSG8962 as compared to HC-3. Hence, the mechanism of salt tolerance is relatively better in HC-3 than in CSG-8962 as found from physiological and yield attributes studied and could be used in crop improvement programme of chickpea for salinity tolerance. 


\section{Introduction}

Chickpea (Cicer arietinum Linnaeus), a member of family Fabaceae, is an ancient self pollinated leguminous crop, diploid annual ( $2 \mathrm{~N}=16$ chromosomes) grown since $7000 \mathrm{BC}$, in different area of the world (Tekeoglu et al., 2000) but its cultivation is mainly concentrated in arid and semi-arid environments such South Asia, West Asia, North Africa, East Africa, Southern Europe, North and South America, and Australia (Arefian et al., 2014; Flowers et al., 2010). In India, Madhya Pradesh, Rajasthan, Maharashtra, Uttar Pradesh, Andhra Pradesh, Karnataka, Chhattisgarh, Bihar and Jharkhand are major chickpea producing states contributing more than $95 \%$ to the total chickpea production. Madhya Pradesh is the single largest producer in the country accounting for over $40 \%$ of total production while Rajasthan, Maharashtra, Uttar Pradesh and Andhra Pradesh contribute about $14 \%$, $10 \%, 9 \%$ and $7 \%$, respectively. The share of Andhra Pradesh and Karnataka has consistently been rising during the past one decade. Further, states like Jharkhand and Chhattisgarh are expanding their area and production of chickpea crop (AICRP, 2014$15)$.

The chickpea seed is a valuable source of carbohydrates and proteins, which together constitute $80 \%$ of the total dry seed weight. The crude protein content of chickpea varies from $17 \%$ to $24 \%$ containing the essential amino acids like tryptophan, methionine and cysteine (Williams and Singh, 1987). Thus, chickpea serves as a main source of dietary protein for more than $80 \%$ of the Indian population which is vegetarian in nature. Chickpea acquires importance as it provides food for humans as well as for livestock. Furthermore, chickpea pod covers and seed coats can also be used as fodder. Chickpea nitrogen fixation plays an important role in maintenance of the soil fertility, particularly in the arid and low rainfall area (Roy et al., 2010).

Soil salinity is known as a major inevitable problem, especially in arid and semi-arid regions of the world and affects about 80 million hectare of arable lands (Flowers et al., 2010), 2.95 million hectare in India and 49.2 thousand hectare in Haryana and this area is expanding (Ali, 2009). Despite the high yield potential of chickpea of over $4000 \mathrm{~kg}$ per hectare (Singh, 1990). The chickpea suffer losses from salinity both in soil and water (Flowers, 2010).

Salinity stress induced production of $\mathrm{H} 2 \mathrm{O} 2$ and may trigger genetically programmed cell suicide (Farouk, 2011). Salinity induced the generation of $\mathrm{H}_{2} \mathrm{O}_{2}$ (Sairam and Tyagi, 2004). The chief toxicity of $\mathrm{H}_{2} \mathrm{O}_{2}$ are production of hydroxyl radicals and other destructive species such as lipid peroxides lead to damage vital cellular macromolecules (Vaidyanathan et al., 2003). Increased in $\mathrm{H}_{2} \mathrm{O}_{2}$ production under salinity has been reported in chickpea roots (Kukreja et al., 2005), tomato leaves (He and Zhu, 2008) and cellular macromolecules (Vaidyanathan et al., 2003). Increased in $\mathrm{H} 2 \mathrm{O} 2$ production under salinity has been reported in chickpea roots (Kukreja et al., 2005), tomato leaves (He and Zhu, 2008).

Lipid peroxidation is the symptom most easily ascribed to oxidative damage. It is an attack upon polyunsaturated fatty acids of the membrane (Heath and Packer, 1968) which lead to the breakdown of lipid and impairment of membrane function. Increased electrolyte leakage and lipid peroxidation were noticed with increased salinity in roots and shoot of green gram (Panda, 2001).

Superoxide dismutase (SOD) catalyzes the dismutation of superoxide into hydrogen peroxide and oxygen (Ashraf and Harris, 
2004) which is in-turn metabolized by the action of peroxidases (Ahmad et al., 2008). SOD originally discovered by McCord and Fridovich (1969) react with superoxide radicals at almost diffusion-limited rates to produce hydrogen peroxide.

CAT converts $\mathrm{H} 2 \mathrm{O} 2$ to water and molecular oxygen. In plant, CAT is found predominantly in peroxisomes and glyoxysomes where it functions chiefly to remove the $\mathrm{H}_{2} \mathrm{O}_{2}$ form during the photorespiration (Geetanjali and Neera, 2008) and also during salt stress and other abiotic stress condition (Willekens et al., 1995).

POX localized in almost all compartments of the plant cell, it plays role in stability the level of $\mathrm{H}_{2} \mathrm{O}_{2}$. Peroxidases, besides their main function in $\mathrm{H}_{2} \mathrm{O}_{2}$ elimination, can also catalyse $\mathrm{O}_{2}$ and $\mathrm{H}_{2} \mathrm{O}_{2}$ formation by a complex reaction in which NADH is oxidized using trace amounts of $\mathrm{H}_{2} \mathrm{O}_{2}$ (Blokhina et al., 2003). Peroxidases are also involved in biosynthesis of cell wall lignifications and suberization (Passardi et al., 2004).

GSTs are a family of multifunctional enzymes that play important roles in oxidative stress resistance (Joseph and Jini, 2011). These dimeric enzymes catalyze the conjugation of GSH to avariety of electrophylic, hydropobic, and often toxic substrates, thereby reducing their toxicity (Hossain and Fujita, 2010).

GPX is ubiquitously occurring enzymes in plant cells that involved in scavenging of $\mathrm{H} 2 \mathrm{O} 2$ and sever to detoxify products of lipid peroxidation formed due to activity of ROS. GPX activity was reported to decrease upon salinization of rice (Lee et al., 2001). However, GPX activity was reported increased in leaves of tomato plant grown with $100 \mathrm{mM} \mathrm{NaCl}$ (He and Zhu, 2008).

GR catalyses the rate limiting last step of AsA-GSH pathway (Ahmad et al., 2008). GR catalases the NADPH dependent reaction of disulphide bond of GSSG and is thus important in providing protection against oxidative damage in plants by maintaining the reduced form of glutathione (Foyer et al., 1991). GR activity has been reported to increase in B.juncea seedlings with increase in salinity level (Verma and Mishra, 2005).

AsA is the most abundant antioxidant and serves as a major contributor to the cellular redox state and protects plants against oxidative damage resulting from aerobic metabolism and a range of biotic and abiotic stresses (Smirnoff, 2000). It is substrate of cAPX and the corresponding organellar isoforms, which are critical components of AsAGSH cycle for $\mathrm{H}_{2} \mathrm{O}_{2}$ detoxification (Nakano and Asada, 1981). Salt stress caused a decreased in total AsA in tomato (He and Zhu, 2008) and wheat (Farouk, 2011).

\section{Materials and Methods}

Two chickpea (Cicer arietinum L.) genotypes CSG-8962 (salt tolerant) and HC-3 (released variety) were raised in pots filled with dune sand $[93.3 \%$ sand $+3.0 \%$ slit $+3.7 \%$ clay, saturation capacity $25 \%, \mathrm{pH} 8.2, \mathrm{ECe}_{2} 0.8 \mathrm{dS}$ $\mathrm{m}^{-1}$ at $25{ }^{\circ} \mathrm{C}, 10.3 \mathrm{mg}(\mathrm{N}) \mathrm{kg}^{-1}, 2.5 \mathrm{mg}(\mathrm{P})$ $\mathrm{kg}^{-1}, 180 \mathrm{mg}(\mathrm{K}) \mathrm{kg}^{-1}$ ] under screen house conditions in the Department of Botany and Plant Physiology, CCS Haryana Agricultural University, Hisar-125 004, India. The seeds before sowing were surface sterilized and inoculated with effective Rhizobium culture (Ca 181). The desired salinity was developed before sowing and maintains four levels (control, 2.0, 4.0 and $6.0 \mathrm{dS} \mathrm{m}^{-1}$ ) of chloride dominated salinity. The crop was supplied with an equal quality of nitrogen free nutrient solution with at regular interval of $15 \mathrm{~d}$. The chloride $\left(\mathrm{Cl}^{-}\right)$dominated salinity was prepared by using a mixture of different salts such as $\mathrm{NaCl}, \quad \mathrm{MgCl}_{2}, \quad \mathrm{MgSO}_{4} \quad$ and $\mathrm{CaCl}_{2}$ where $\mathrm{Na}: \mathrm{Ca}+\mathrm{Mg}$ was in the ratio of $1: 1$ and $\mathrm{Ca}: \mathrm{Mg}$ in the ratio of $1: 3$, the $\mathrm{Cl}: \mathrm{SO}_{4}$ ratio was $7: 3$ on 
a meq basis. Sampling was done at 50-60 days after sowing (DAS).

$\mathrm{H}_{2} \mathrm{O}_{2}$ content of the leaves and roots was determined by a modified Patterson et al., (1984) method. MDA is a product of lipid peroxidation and was measured by thiobarbituric acid (TBA) reaction with minor modifications of the method of Heath and Packer (1968). The activity of SOD was assayed by measuring its ability to inhibit the photochemical reduction of NBT according to Beauchamp and Fridovich (1971). The CAT activity was estimated according to the procedure described by Aebi (1984). GR activity was analysed by the method of Halliwell and Foyer (1978). The APX enzyme activity was determined according to the method described by Nakano and Asada (1981). The procedure of Siegel and Siegel (1969) was followed for estimating peroxidase activity. Ascorbic acid content was determined with a modification of the procedure of Takahama and Oniki (1992). The GPX activity was estimated according to the procedure described by Hossain and Fujita (2010).

Data were subjected to analysis of variance (ANOVA) using online Statistical Analysis Package (OPSTAT, Computer Section, CCS Haryana Agricultural University, Hisar, Haryana, India) and treatment means were compared by the least significant differences $(\mathrm{LSD})(\mathrm{p}<0.05)$.

\section{Results and Discussion}

The $\mathrm{H}_{2} \mathrm{O}_{2}$ content increased significantly by 0.380 to 0.625 and 0.366 to 0.579 (moles $\mathrm{g}^{-1}$ DW) $x 10_{-4}$ ) in leaves at 50-60 DAS in the genotypes CSG-8962 and HC-3, respectively with increasing the level of salinity. In roots, $\mathrm{H} 2 \mathrm{O} 2$ content increased significantly from 0.260 to 0.470 in the genotype CSG-8962 and 0.217 to 0.401 in the HC-3 (Figure $1 \mathrm{a}$ ).
Increased $\mathrm{H}_{2} \mathrm{O}_{2}$ production under salinity has been reported in chickpea roots (Kukreja et al., 2005), tomato leaves (He and $\mathrm{Zhu}, 2008$ ). A progressive increase in $\mathrm{H}_{2} \mathrm{O}_{2}$ content with increasing $\mathrm{NaCl}$ concentration was observed in Brassica juncea (Verma and Mishra, 2005).

In leaves, a significant accumulation of MDA content was observed in both the genotypes under salinity levels (Figure 1 b). This increase was from 13.40 to $21.43 \mathrm{n}$ moles $\mathrm{g}^{-}$ ${ }^{1}$ dry weight in the genotypes CSG-8962 and 13.38 to 17.43 in HC-3. In roots, an increase from 10.35 to $16.59 \mathrm{n}^{-}$moles $\mathrm{g}^{-1}$ dry weight in MDA content was observed in the genotype CSG-8962, however, in HC-3, this was from 10.55 to 13.83 with increasing levels of salinity. Increase in electrolyte leakage with increasing saline stress has been reported in wheat leaf senescence (Farouk, 2011) and in wheat young leaf (Farooq and Azam, 2006). Similar results have been observed in green gram (Panda, 2001) and chickpea (Kukreja et al., 2006; Sheokand et al., 2008).

The specific activity of SOD in leaves increased from 1.20 to 10.70 and 1.36 to 11.67 Units $\mathrm{mg}^{-1}$ protein at $6.0 \mathrm{dS} \mathrm{m}^{-1}$ over their control in genotypes CSG-8962 and HC-3 (Figure $2 \mathrm{a}$ ). In roots the specific activity of SOD increased from 1.83 to 10.46 and 1.76 to 12.65 Units $\mathrm{mg}^{-1}$ protein in both the genotypes CSG-8962 and HC-3, respectively. Kukreja et al., (2006) reported two-fold increase in the specific activity of SOD activity in chickpea roots under short term salinization.

The specific activity of CAT in leaves increased from 2.23 to 6.93 and 2.60 to 8.50 Units $\mathrm{mg}^{-1}$ protein in both genotypes CSG8962 and HC-3, respectively. In roots, 3.04 to 6.05 in CSG-8962 and 3.35 to 7.36 in HC-3 increase the specific activity of CAT was observed (Figure 2 b). Catalase (CAT) is a key antioxidant enzyme which converts $\mathrm{H}_{2} \mathrm{O}_{2}$ to water and molecular oxygen. 
Table.1 Changes in yield and its attributes of chickpea genotypes under different salinity levels

\begin{tabular}{|c|c|c|c|c|c|c|}
\hline \multirow[b]{2}{*}{ Parameters } & \multirow[b]{2}{*}{ Genotypes } & \multicolumn{5}{|c|}{ Salinity levels $\left(\mathrm{dS} \mathrm{m}{ }^{-1}\right)$} \\
\hline & & 0 & 2 & 4 & 6 & $\mathrm{M}$ \\
\hline \multirow{4}{*}{ Branches plant ${ }^{-1}$} & $\mathrm{HC}-3$ & 9.00 & 8.33 & 8.00 & 6.33 & 7.91 \\
\hline & CSG-8962 & 8.00 & 7.00 & 6.6 & 5.00 & \multirow[t]{2}{*}{6.91} \\
\hline & Mean & 8.50 & 8.16 & 7.33 & 5.66 & \\
\hline & $\mathrm{CD}$ at $5 \%$ & \multicolumn{5}{|c|}{ Genotype $=0.30 ;$ Salinity $=0.43 ; \mathrm{G} \times \mathrm{S}=\mathrm{NS}$} \\
\hline \multirow{4}{*}{ Pods plant ${ }^{-1}$} & $\mathrm{HC}-3$ & 13.66 & 13.33 & 11.33 & 8.66 & 11.75 \\
\hline & CSG-8962 & 12.66 & 11.33 & 8.33 & 7.66 & 10.00 \\
\hline & Mean & 13.16 & 12.33 & 9.83 & 8.16 & \\
\hline & $\mathrm{CD}$ at $5 \%$ & \multicolumn{5}{|c|}{ Genotype $=0.50 ;$ Salinity $=0.71 ; \mathrm{G} \times \mathrm{S}=1.00$} \\
\hline \multirow{4}{*}{ Seeds pod ${ }^{-1}$} & $\mathrm{HC}-3$ & 1.66 & 1.33 & 1.33 & 1.33 & 1.41 \\
\hline & CSG-8962 & 1.66 & 1.30 & 1.00 & 1.00 & 1.24 \\
\hline & Mean & 1.66 & 1.31 & 1.16 & 1.16 & \\
\hline & $\mathrm{CD}$ at $5 \%$ & \multicolumn{5}{|c|}{ Genotype $=0.04 ;$ Salinity $=0.05 ; \mathrm{G} \times \mathrm{S}=0.08$} \\
\hline \multirow{4}{*}{100 seed weight $(\mathrm{g})$} & HC-3 & 29.36 & 24.72 & 15.75 & 10.97 & \multirow[t]{3}{*}{20.20} \\
\hline & CSG-8962 & 13.68 & 10.82 & 8.83 & 7.47 & \\
\hline & Mean & 21.52 & 17.77 & 12.29 & 9.22 & \\
\hline & $\mathrm{CD}$ at $5 \%$ & \multicolumn{5}{|c|}{ Genotype $=0.51 ;$ Salinity $=0.72 ; \mathrm{G} \times \mathrm{S}=1.02$} \\
\hline \multirow{4}{*}{ Seed yield plant ${ }^{-1}(\mathrm{~g})$} & $\mathrm{HC}-3$ & 26.00 & 25.00 & 23.00 & 19.00 & 23.25 \\
\hline & CSG-8962 & 25.00 & 23.00 & 22.33 & 16.00 & \multirow[t]{3}{*}{21.58} \\
\hline & Mean & 25.50 & 24.00 & 22.66 & 17.50 & \\
\hline & $\mathrm{CD}$ at $5 \%$ & \multicolumn{4}{|c|}{ Genotype $=0.59 ;$ Salinity $=0.84 ; \mathrm{G} \times \mathrm{S}=1.19$} & \\
\hline
\end{tabular}

Figure.1 Changes in hydrogen peroxides $\left(\mathrm{H}_{2} \mathrm{O}_{2}\right)$ content (a) and lipid peroxidation (MDA) content (b) of chickpea genotypes under different salinity levels

(a)

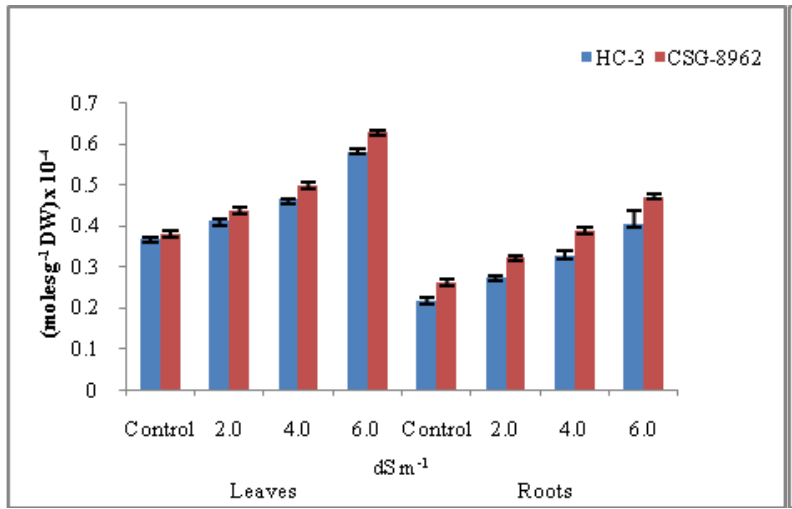

(b)

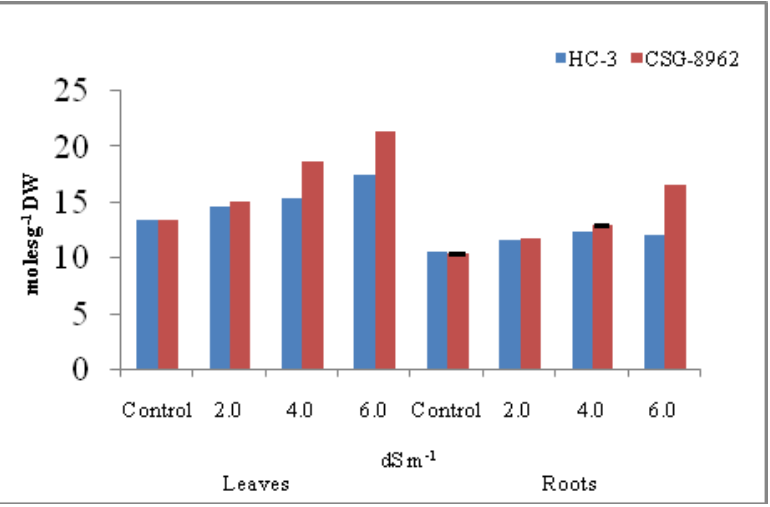


Figure.2 Changes in specific activity of Superoxide dismutase (a), Catalase (b), Peroxidase (c), Ascorbate peroxidase (d), Glutathione peroxidase (e), Glutathione reductase (f), Glutathione Stransferase (g) and Ascorbate (h) of chickpea genotypes under different salinity levels

(a)

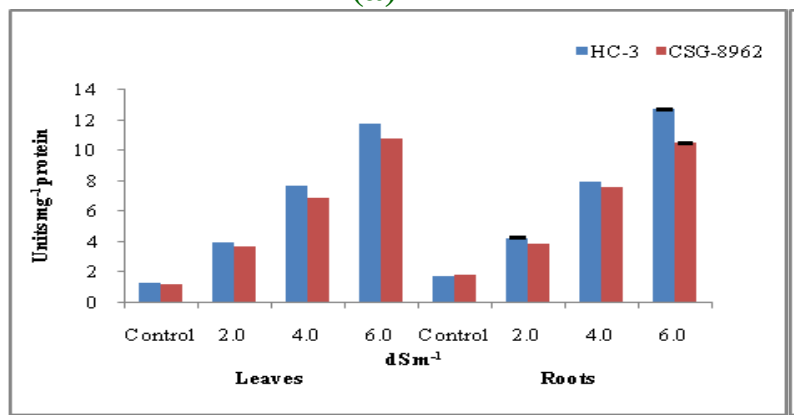

(c)

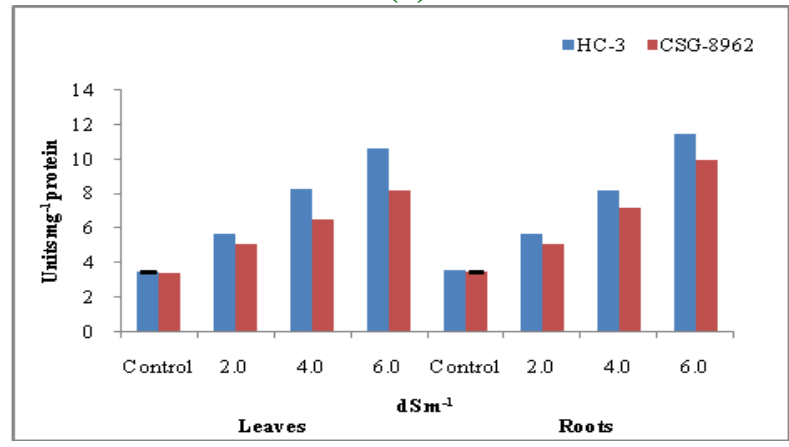

(e)

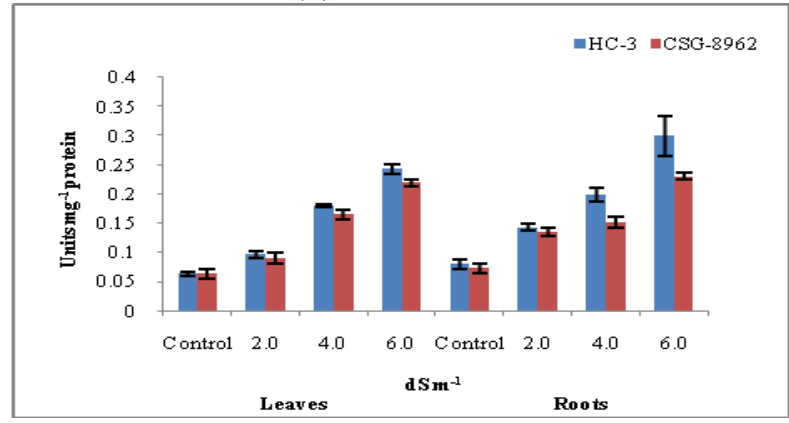

(g)

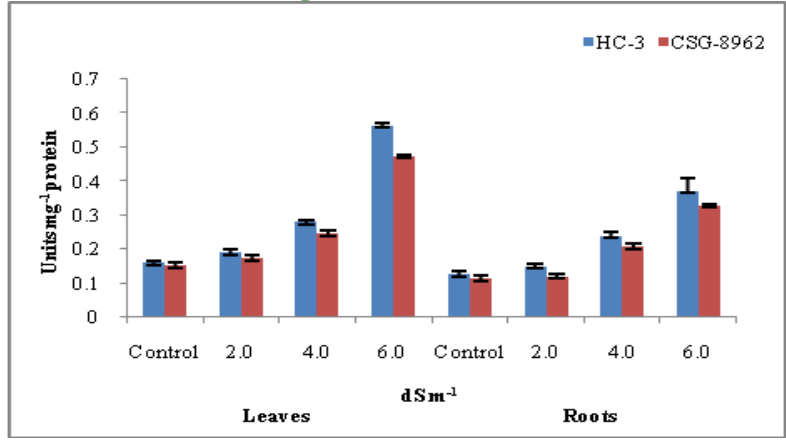

(b)

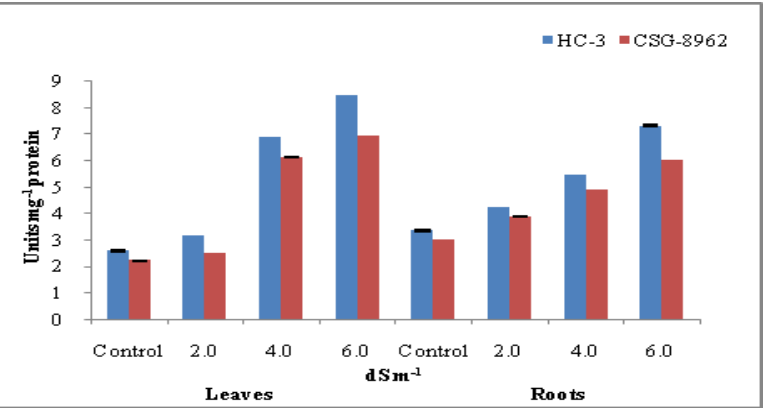

(d)

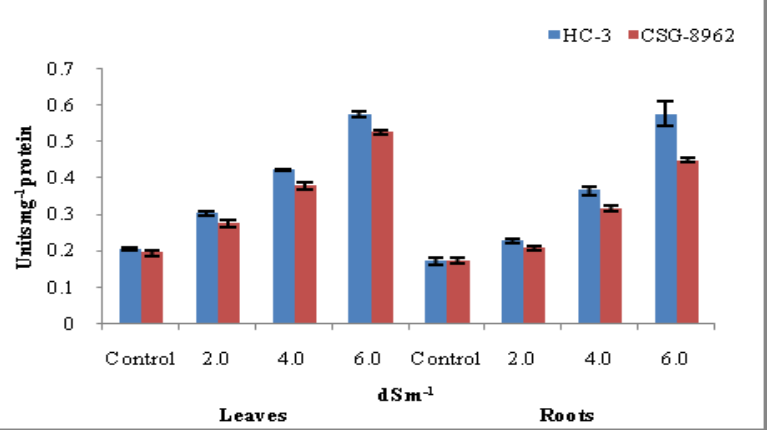

(f)

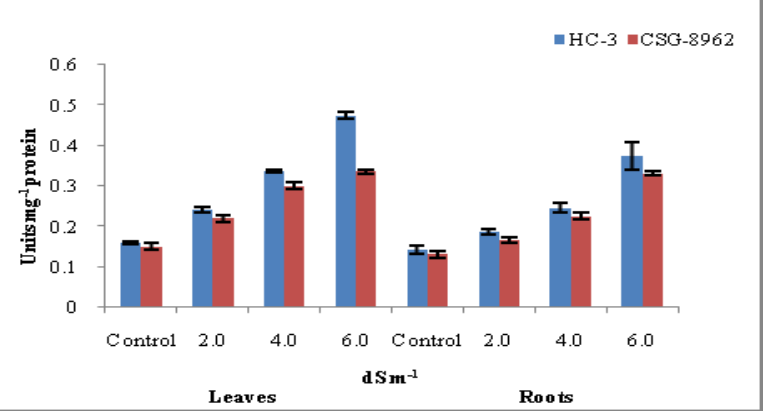

(h)

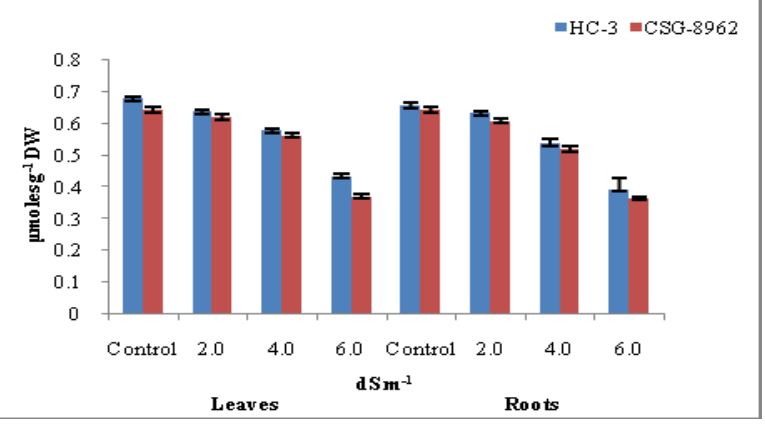


An increased in the specific activities of the CAT is related to an increase in stress tolerance (Sairam and Srivastava, 2001).

In leaves, Specific activity of POX increased was from 3.41 to 8.20 and 3.46 to 10.59 Units $\mathrm{mg}^{-1}$ protein in the genotypes CSG-8962 and HC-3, respectively. In roots, increase in the specific activity of POX from 3.46 to 9.93 and 3.61 to 11.41 Units $\mathrm{mg}^{-1}$ protein was observed in genotypes CSG-8962 and HC-3, respectively with increasing levels of salinity from control to $6.0 \mathrm{dS} \mathrm{m}^{-1}$ (Figure $2 \mathrm{c}$ ). Experimental evidence also showed that salinity causes increases in POX activity in Cassia angustifolia (Agarwal and Pandey, 2004), Brassia napus (Dolatabadion et al., 2008) and chickpea plants (Sheokand et al., 2008).

The specific activity of APX increased from 0.193 to 0.525 and 0.204 to 0.574 Units $\mathrm{mg}$ ${ }^{1}$ protein in genotypes CSG-8962 and HC-3, respectively at 50-60 DAS in leaves. The specific activity of APX is 0.173 to 0.506 in CSG-8962 and 0.170 to 0.447 Units $\mathrm{mg}^{-}$ ${ }^{1}$ protein in HC-3 in roots (Figure $2 \mathrm{~d}$ ). Hernandez et al., (2000) reported that tolerant Pisum sativum response to long term $\mathrm{NaCl}$ treatment increased Ascorbate peroxidase 3 fold.

The GPX specific activity increased from 0.063 to 0.220 in CSG-8963 and 0.063 to 0.243 in $\mathrm{HC}-3$ Units $\mathrm{mg}^{-1}$ protein in leaves. An increase from 0.073 to 0.230 and 0.080 to 0.300 Units $\mathrm{mg}^{-1}$ protein in GPX specific activity was observed in both genotypes CSG8962 and HC-3, respectively in roots (Figure 2 e). GPX activity was reported to decrease upon salinization of rice (Lee et al., 2001). However, GPX activity was reported increased in leaves of tomato plant grown with $100 \mathrm{mM} \mathrm{NaCl}$ (He and Zhu, 2008).

In leaves the specific activity of GR increased from 0.150 to 0.366 and 0.159 to 0.475 Units $\mathrm{mg}^{-1}$ protein in genotype CSG-8962 and HC3 , respectively with increasing levels of salinity from control to $6.0 \mathrm{dS} \mathrm{m}{ }^{-1}$ at $50-60$ DAS. In roots, the specific activity of GR increased was from 0.132 to 0.302 and 0.143 to 0.375 Units $\mathrm{mg}^{-1}$ protein in genotypes CSG-8962 and HC-3, respectively (Figure 2 $\mathrm{f})$. The increase in GR activity has also been observed in salt tolerant varieties of rice (Dionisio and Tobita, 1998), pea (Hernandez et al., 2000), in Brassica juncea (Verma and Mishra, 2005) and wheat (Sairam et al., 2002) than their respective sensitive varieties.

The specific activity of GST increase from 0.153 to 0.473 in CSG-8962 and 0.162 to 0.564 Units $\mathrm{mg}^{-1}$ protein in $\mathrm{HC}-3$ was observed in leaves. In roots increase from 0.115 to 0.327 and 0.128 to 0.373 Units $\mathrm{mg}^{-}$ ${ }^{1}$ protein specific activity of GST were observed in genotypes CSG-8962 and HC-3, respectively (Figure $2 \mathrm{~g}$ ). GST increased by $95 \%$ was reported at $10 \mathrm{dS} \mathrm{m}{ }^{-1}$ salinity level in chickpea roots (Kukreja et al., 2005).

In contrast to antioxidant enzyme activities, the AsA content decreased in both leaves and roots with increasing salinity levels from control to $6.0 \mathrm{dS} \mathrm{m}^{-1}$. In leaves the AsA content decreased from 0.645 to 0.372 and 0.681 to $0.435 \mu$ moles $\mathrm{g}^{-1}$ dry weight were observed in genotypes CSG-8962 and HC-3, respectively. In roots, a decreased from 0.645 to 0.365 in CSG-8962 and 0.659 to $0.395 \mathrm{HC}$ $3 \mu$ moles $\mathrm{g}^{-1}$ dry weight were observed (Figure $2 \mathrm{~h}$ ). The decline in Ascorbate content was also observed with increasing salinity level in chickpea (Kukreja et al., 2006), tomato (He and Zhu, 2008) and wheat (Farouk, 2011). Hernandez et al., (1999; 2000) reported $\mathrm{NaCl}$ concentration at $70 \mathrm{mM}$ decreased AsA in both $\mathrm{NaCl}$ tolerant and $\mathrm{NaCl}$ sensitive pea cultivars.

Number of branches plant ${ }^{-1}$ reduced to $37.5 \%$ and $29.6 \%$ in the genotypes CSG-8962 and $\mathrm{HC}-3$, respectively, at $6.0 \mathrm{dS} \mathrm{m} \mathrm{m}^{-1}$ salinity 
level. The number of pods plant ${ }^{-1}$ reduced to $39.5 \%$ and $36.6 \%$ in the genotypes CSG8962 and HC-3, respectively. The percent reduction in number of seeds pod ${ }^{-1}$ was 39.7 $\%$ in CSG-8962 and $19.8 \%$ in HC-3. The percent reduction in test weight was $7.4 \%$ in CSG-8962 and $10.9 \%$ in $\mathrm{HC}-3$ at $6.0 \mathrm{dS} \mathrm{m}^{-1}$. The percent reduction in seed yield plant $^{-1}$ was 27.3, 43.8 and 58.0 \% and 19.0, 31.5 and $52.0 \%$ in the genotypes CSG-8962 and HC-3, respectively at 2.0, 4.0 and $6.0 \mathrm{dS} \mathrm{m}^{-1}$ salinity level with respect to their control (Table 1). Turner et al., (2013) also observed that saline treatment $(40 \mathrm{mM} \quad \mathrm{NaCl})$ significantly decreased the seed yield in chickpea genotypes and genotypic variation for salinity tolerance exists in chickpea.

In conclusion, HC-3 showed comparative better perform than CSG-8962 on the basis of various biochemical traits related to hydrogen peroxide, lipid peroxidation, antioxidant defense system and yield attributes under saline conditions.

Abbreviations: APX - Ascorbate peroxidse, CAT - Catalase, dS $m^{-1}$ - DeciSiemens per metre, DAS - Days after sowing, DW - Dry weight, GPX - Glutathione peroxidase, GR Glutathione reductase and GST - Glutathione $-\mathrm{S}$ - transferase, $\mathrm{H}_{2} \mathrm{O}_{2}$ - Hydrogen peroxide, MDA - Malondialdehyde, POX - Peroxidase, SOD-Superoxide dismutase.

\section{References}

Aebi, H. (1984). Catalase in vitro. Methods in Enzymology 105: 121-126.

Agarwal, S. and Pandey, V. (2004). Antioxidant enzyme responses to $\mathrm{NaCl}$ stress in Cassia angustifolia. Biologia Plantarum 8: 555-560.

Ahmed, Khalafallah, A., Tawfik, K.M., Zinab, A. and EI-Gawad, A. (2008). Tolerance of seven faba bean varieties to drought and salt stress. Research Journal of Agriculture and Biological Sciences 4:
175-186.

AICRP, (2014-15). All india Cordinated Research Project on Chickpea. Project Coordinator's Report.

Ali, Q. (2009). Alleviation of salt stress through nutrient management. ICAR Azad Hind Store Private Limited Publisher. pp.132157.

Arefian, M., Vessal, S. and Bagheri, A. (2014). Biochemical changes and SDS-PAGE analyses of chickpea (Cicer arietinum L.) genotypes in response to salinity during the early stages of seedling growth. Journal of Biological and Environmental Science 8(23): 99-109.

Ashraf, M. and Harris, P.J.C. (2004). Potential biochemical indicators of salinity tolerance in plants. Journal of Plant Science 166: 3-16.

Beauchamp, C. and Fridovich, I. (1971). Superoxide dismutase: Improved assays and an assay applicable to acrylamide gels. Analytical Biochemistry 44: 276287.

Blokhina, O., Virolainen, E. and Fagerstedt. K.V. (2003). Antioxidants, oxidative damage and oxygen deprivation stress: a review. Annals of Botany 91: 179-194.

Dionisio-Sese, M.L. and Tobita, S. (1998). Antioxidant responses of rice seedlings to salinity stress. Plant Science 135: 1-9.

Dolatabadion, A., Sanavy, S.A.M.M. and Chashmi, N.A. (2008). The effects of foliar application of ascorbic acid (vitamin C) on antioxidant enzymes activities, lipid peroxidation and proline accumulation of canola (Brassica napus L.) under conditions of salt stress. Journal of Agricultural Science 194: 206-213.

Farooq, S. and Azam, F. (2006). The use of cell membrane stability (CMS) technique to screen for salt tolerant wheat varieties. Journal of Plant Physiology 163: 629637.

Farouk, S. (2011). Ascorbic acid and $\alpha$ Tocopherol minimize salt-induced wheat leaf senescence. Journal of Stress Physiology \& Biochemistry 7: 58-79.

Flowers, T.J., Gaur, P.M., Gowda, C.L.L., 
Krishnamurthy, L., Samineni, S., Siddique, K.H.M., Turner, N.C., Vadez, V., Varshney, R.K. and Colmer, T.D. (2010). Salt sensitivity in chickpea. Plant Cell and Environment 33: 490-509.

Foyer, C.H.M., Lelandais, C.G. and Kunert, K.J. (1991). Effect of elevated cytosolic glutathione pool and photosynthesis in leaves under normal and stress conditions. Plant Physiology 97: 863- 872.

Geetanjali, M. and Neera, G. (2008) Salinity and its effects on the functional biology of legumes. Acta Physiologiae Plantarum 30: 595-618.

Halliwell, B. and Foyer, C.H. (1978). Properties and physiological functions of a glutathione reductase purified from spinach leaves by affinity chromatography. Planta 139: 9-17.

He, Y. and Zhu, Z.J. (2008). Exogenous salicylic acid alleviates $\mathrm{NaCl}$ toxicity and increases antioxidative enzyme activity in Lycopersicon esculenttum. Biologia Plantarum 52: 792-795.

Heath, R.L. and Packer, L. (1968). Photoperoxidation in isolated chloroplasts. I. Kinetics and stoichiometry of fatty acid peroxidation. Archives of Biochemistry and Biophysics 125: 189198.

Hernandez, J.A., Campillo, A., Jimenez, A., Alarson, J.J. and Sevilla, F. (1999). Response of antioxidant system and leaf water relation to $\mathrm{NaCl}$ stress in pea plants. New Phytologist 14: 241-251.

Hernandez, J.A., Jimenez, A., Mullineaux, P. and Sevilla, F. (2000). Tolerance of pea (Pisum sativum L.) to long term salt stress is associated with induction of antioxidant defenses. Plant Cell Environment 23: 853-862.

Hossain, M.A. and Fujita. M. (2010). Evidence for a role of exogenous glycinebetaine and proline in antioxidant defense and methylglyoxal detoxification systems in mung bean seedlings under salt stress. Physiology and Molecular Biology of Plants 16: 19-29.

ICAR-Indian Institute of Pulses Research,
Kanpur, Uttar Pradesh, India.

Joseph, B. and Jini, D. (2011). Development of salt stress-tolerant plants by gene manipulation of antioxidant enzymes. Asian Journal of Agricultural Research 5: 17-27.

Kukreja, S., Nandwal, A.S., Kumar, N., Sharma, S.K., Kundu, B.S., Unvi, V. and Sharma, P.K. (2006). Responses of chickpea roots to short term salinization and desalinization: plant water status, ethylene evolution, antioxidant activity and membrane integrity. Physiology and Molecular Biology of Plants 12: 67-73.

Kukreja, S., Nandwal, A.S., Kumar, N., Sharma, S.K., Sharma, S.K., Unvi, V.K. and Sharma, P.K. (2005). Plant water status, $\mathrm{H} 2 \mathrm{O} 2$ scavenging enzymes, ethylene evolution and membrane integrity of Cicer arietinum roots as affected by salinity. Biologia Plantarum 49: 305-308.

Lee, D.H., Kim, Y.S. and Lee, C.B. (2001). The inductive responses of antioxidant enzymes by salt stress in the rice (Oryza sativa). Journal of Plant Physiology 158: 737-745.

McCord, J.M. and Fridovichi, I. (1969). Superoxide dismutase. An enzymic function for erythocuprein (hemocuprein). Journal of Biological Chemistry 244: 6049-6055.

Nakano, Y. and Asada, K. (1981). Hydrogen peroxide is scavenged by ascorbate specific peroxidase in spinach chloroplasts. Plant Cell Physiology 22: 867-880.

Panda, S.K. (2001). Oxidative response of green gram seeds under salinity stress. Indian Journal of Plant Physiology 6: 438-444.

Passardi, F., Penel, C. and Dunand, C. (2004). Performing the paradoxical: how plant peroxidases modify the cell wall. Trends Plant Science 9: 534-540.

Roy, F., Boye, J. and Simpson, B. (2010). Bioactive proteins and peptides in pulse crops: Pea, chickpea and lentil. Food Research International 43: 432-442.

Sairam, R.K. and Srivastava, G. C. (2001). 
Water Stress Tolerance of Wheat (Triticum aestivumL.): Variations in hydrogen peroxide accumulation and antioxidant activity in tolerant and susceptible genotypes. Journal of Agronomy and Crop Science 186(1): 6370.

Sairam, R.K. and Tyagi, A. (2004). Physiology and molecular biology of salinity stress tolerance in plants. Current Science 86: 407-421.

Sairam, R.K., Rao, K.V. and Srivastava, G.C. (2002). Differential responses of wheat genotypes to long term salinity stress in relation to oxidative stress, antioxidant activity and osmolytic concentration. Plant Science 163: 1037-1046.

Sheokand, S., Kumari, A. and Sawhney, V. (2008). Effect of nitric oxide and putrescine on antioxidative responses under $\mathrm{NaCl}$ stress in chickpea plants. Physiology and Molecular Biology of Plants 14: 355-362.

Siegel, B.S. and Siegel, S.M. (1969). Anomalous substrate specificities among the algal peroxidases. American Journal of Botany 57: 285-287.

Singh, K.B. (1990). Present Status and Future Prospects of Chickpea Crop Production and Improvement in the Mediterranean Countries, (Eds. M. C. Saxena, J. I. Cubero and J. Wery). Options Mediterraneennes, Serie A: Seminaires Mediterraneens, Numero 9. Zaragoza, Spain: CIHEAM. pp. 25-34.

Smirnoff, N. (2000). Ascorbic acid, metabolism and functions of a multifaceted molecule. Current Opinion in Plant Biology 3: 229-
235.

Takahama, U. and Oniki, T. (1992). Regulation of peroxidases-dependent oxidation of phenolic in the apoplast of spinach leaves by ascorbate. Plant Cell Physiology 33: 379-387.

Tekeoglu, M., Santra, D.K., Kaiser, W.J. and Muehlbauer, F.J. (2000). Ascochyta blight resistance in three chickpea recombinant inbred line populations. Crop Science 40: 1251-56.

Turner, N.C., Colmer, T.D., Quealy, J., Pushpavalli, R., Krishnamurthy, L., Kaur, J., Singh, G., Siddique, K.H. M. and Vadez, V. (2013). Salinity tolerance and ion accumulation in chickpea (Cicer arietinum L.) subjected to salt stress. Plant Soil 365:347-361.

Vaidyanathan, H., Sivakumar, P., Chakrobarty, R. and Thomas, G. (2003). Scavenging of reactive oxygen species in $\mathrm{NaCl}$ - stressed rice (Oryza sativa L.) differential responses in salt tolerant and salt sensitive varieties. Plant Science 165: 1411-1418.

Verma, S. and Mishra, S.N. (2005). Putrescine alleviation of growth in salt stressed Brassica juncea by inducing antioxidative defence system. Journal Plant Physiology 162: 669-677.

Willekens, H., Montagu, M. and Camp, W. (1995). Catalase in plants. Molecular Breeding 1: 207-228.

Williams, P.C. and Singh, U. (1987). The chickpea. (Eds. Saxena, M. and Singh, K.B.). CAB International, Wallingford, Oxon, United Kingdom. pp. 329-356.

\section{How to cite this article:}

Dharamvir, Neeraj Kumar, Ajeev Kumar, Mahesh Kumar and Parveen Kumar. 2018. Salinity Induced Changes in hydrogen peroxide, Lipid Peroxidation, Antioxidant Enzymes Activities and Yield Attributes in Chickpea (Cicer arietinum L.) Cultivars. Int.J.Curr.Microbiol.App.Sci. 7(12): 2034-2043. doi: https://doi.org/10.20546/ijcmas.2018.712.234 